however, that the prophylaxis described here is dangerous, and its value in the treatment of childhood acute lymphoblastic leukaemia is very well documented.

1 Peylan-Ramu, N, et al, New England fournal of Medicine, 1978, 298, 815.

${ }^{2}$ Enzmann, D R, and Lane, B, fournal of Pediatrics, 1978, 92, 535.

3 Ochs, J, et al, Proceedings of the American Society of Clinical Oncology, $1978,19,391$.

${ }^{4}$ Hahn, F S Y, and Rim, K, American fournal of Roentgenology, Radium Therapy, and Nuclear Medicine, 1976, 126, 593.

${ }^{5}$ Enzmann, D R, and Lane, B, Journal of Computer Assisted Tomography, $1977,1,410$.

(Accepted 1 November 1978)

Bristol Royal Hospital for Sick Children, Bristol BS2 8B]

R E DAY, MB, MRCP, senior registrar in paediatric neurology (present appointment: consultant paediatrician, Glasgow Royal Hospital for Sick Children)

J KINGSTON, MB, MRCP, research registrar

J A BULLIMORE, MB, FRCR, consultant radiotherapist and oncologist

M G MOTT, BSC, MRCP, consultant paediatric oncologist

Frenchay Hospital, Bristol BS16 1LE

J L G THOMSON, FRCP, FRCR, consultant neuroradiologist

\section{Inappropriate antidiuretic hormone secretion associated with neurohypophyseal choristoma}

Neurohypophyseal choristomas are tumours that have been found in $6^{\circ}{ }^{\circ}$ of routine necropsy specimens ${ }^{1}$ but rarely give rise to symptoms. ${ }^{2}$ We report what we believe to be the first example of the syndrome of inappropriate antidiuretic hormone secretion (SIADH) associated with a neurohypophyseal choristoma.

\section{Case report}

A 42-year-old housewife presented with weight loss, anorexia, and vomiting. Barium meal examination and gastroscopy showed pyloric narrowing. Vagotomy and pyloroplasty were done for presumed benign hypertrophic pyloric stenosis. Duodenal histology was normal. During the operation she developed a sinus tachycardia and for three days her ECG showed pronounced anterior ST segment elevation with $\mathrm{T}$ wave inversion. Cardiac enzyme concentrations were normal. Her plasma concentration of urea was $1.7 \mathrm{mmol} / 1(10.2 \mathrm{mg} / 100 \mathrm{ml})$, sodium $131 \mathrm{mmol}(\mathrm{mEq}) / 1$, potassium $4.6 \mathrm{mmol}(\mathrm{mEq}) / 1$, and glucose $4.3 \mathrm{mmol} / 1(77.4 \mathrm{mg} / 100 \mathrm{ml})$. During convalescence her vomiting and anorexia continued and she developed headaches: 50 days after her operation she was started on metoclopramide and nortriptyline. Six days later she was readmitted as an emergency, drowsy but moving all four limbs purposefully. Reflexes, pupils, and optic

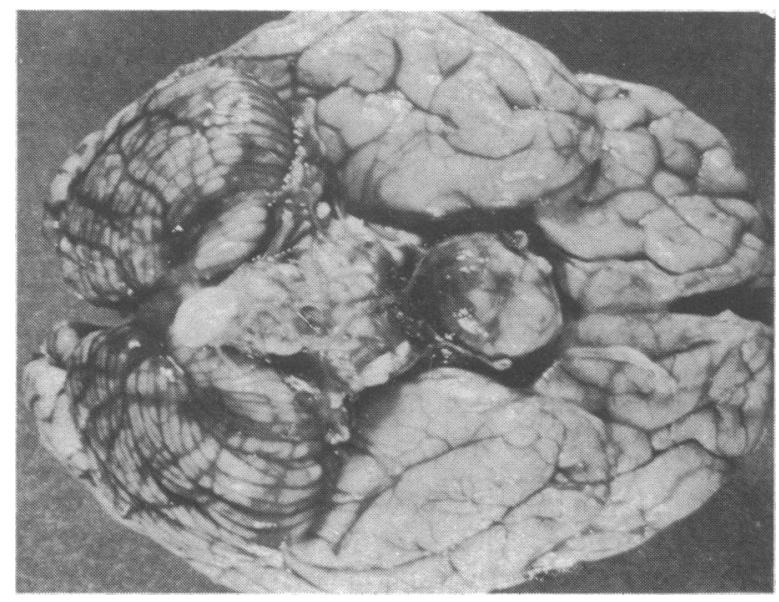

Base of brain showing neurohypophyseal choristoma. fundi were normal. Visual fields could not be tested because of impaired consciousness. Plasma concentration of urea was $2 \mathrm{mmol} / \mathrm{l}(12 \mathrm{mg} / 100 \mathrm{ml})$, sodium $123 \mathrm{mmol}(\mathrm{mEq}) / 1$, potassium $3.1 \mathrm{mmol}(\mathrm{mEq}) / \mathrm{l}$, bicarbonate 25 $\mathrm{mmol}(\mathrm{mEq}) / 1$, and plasma osmolality $258 \mathrm{mmol}(\mathrm{mosmol}) / \mathrm{kg}$. After overnight water deprivation plasma osmolality was $250 \mathrm{mmol}(\mathrm{mosmol}) / \mathrm{kg}$ with urine osmolality $320 \mathrm{mmol}(\mathrm{mosmol}) / \mathrm{kg}$, compatible with the diagnosis of SIADH. Chest $x$-ray examination was normal and an ECG showed anterior $\mathrm{T}$ wave inversion. Skull $x$-ray examination showed erosion of the posterior clinoid processes. EEG showed diffuse abnormality compatible with a metabolic disorder or hypothalamic lesion.

The day after admission she suddenly became unresponsive with one fixed, dilated pupil and extensor plantar responses. There was a midline shift on the echoencephalogram. Burr holes showed no haematomas but internal hydrocephalus was demonstrated. Ventricular drainage was instituted. Computerised axial tomography revealed a hypothalamic lesion which angiography showed to be highly vascular. It was considered to be an astrocytoma. The patient remained deeply unconscious. Because of the site and presumed nature of the lesion management was conservative. She died two days later. Necropsy showed a hypothalamic tumour $3.5 \mathrm{~cm}$ in diameter (figure). This had the histological features of a choristoma, being a capsulated tumour composed of large eosinophilic cells heavily granulated with PASpositive material. There was old and recent haemorrhage into the tumour. The pituitary, heart, and coronary arteries were normal.

\section{Comment}

Among the many causes of SIADH are drugs and intracerebra 1 lesions. ${ }^{3}$ We do not think it was drug induced in our patient since both the clinical and biochemical features of the syndrome preceded any medication by several weeks. SIADH has been reported due to intracerebral infection, haemorrhage, and tumours, ${ }^{3}$ but has not, it seems, been reported before in association with a neurohypophyseal choristoma. Choristomas are benign tumours of "obscure derivation and of little clinical significance," most of which are microscopic. ${ }^{1}$ With only 18 symptomatic patients reported, ${ }^{2}$ the value of surgery or radiotherapy is not clear. Fourteen of the 18 had visual disturbance, which our patient had not reported. One had amenorrhoea with decreased gonadotrophin concentrations. Our patient is the only other with hormonal disturbance, and probably her SIADH was due to hypothalamic damage by the tumour rather than to $\mathrm{ADH}$ secretion from the tumour. ECG ST segment elevation and T wave changes with no evidence of myocardial damage have been reported in intracranial disease,${ }^{5}$ and we think that the choristoma probably caused the ECG changes in our case-particularly since the cardiac enzyme concentrations, heart, and coronary arteries were normal.

We thank Dr B F Clarke and Mr P Harris for permission to report a patient under their care.

1 Luse, S A, and Kernohan, J W, Cancer, 1955, 8, 616.

2 Houtteville, J P, et al, Review of Neurology (Paris), 1976, 132, 589.

3 Mendoza, S A, Pediatric Clinics of North America, 1976, 23, 681.

${ }^{4}$ Martins, A N, Handbook of Clinical Neurology, ed P J Vinken and G W Bruyn, vol 17, p 425. Amsterdam, North Holland Publishing Co, 1974. 5 Levine, H D, American fournal of Medicine, 1953, 15, 344.

(Accepted 25 October 1978)

Department of Medicine, University of Edinburgh, The Royal Infirmary, Edinburgh EH3 9YW

C HASLETT, MB, house physician

N J DOUGLAS, MRCP, lecturer

ONE HUNDRED YEARS AGO It is, I believe, a generally accepted fact that opiates in delirium tremens do more harm than good, except occasionally in very protracted cases; and even then, only the amount of a full dose should be given in the twenty-four hours. In chloral-hydrate and capsicum, we have two powerful remedies. The latter I have used for more than twelve years with unvarying success; it has never failed, no matter how violent the patient may have been, and I have had a man under treatment who required six strong men to hold him in bed. After four doses of the capsicum (thirty grains every hour in bolus), he fell into a calm sleep, and awoke a rational being. This was an extreme case, but milder cases simply require smaller doses of the capsicum. (British Medical fournal, 1878.) 